Reprinted with permission from: Weed Technology. 1994. 8(3):494-498.

Published and copyrighted by: Weed Science Society of America. http://www.wssa.net

\title{
Leafy spurge (Euphorbia esula) control with imidazolinone and sulfonylurea herbicides ${ }^{1}$
}

\author{
ROBERT N. STOUGAARD, ROBERT A. MASTERS, and SCOTT J. NISSEN \\ Asst. Prof., Dep. Agron., Range Sci., U.S. Dep. Agric., and Asst. Prof., Dep. Agron., Univ. Nebraska, Lincoln, NE \\ 68583-0915. Current address of R.N. Stougaard: Northwestern Agric. Res. Cent., Kalispell, MT 59901.
}

\begin{abstract}
:
Experiments were conducted to determine the efficacy of imidazolinone and sulfonylurea herbicides applied alone or in combination to control leafy spurge. Imazapyr (840 g ai/ha), imazethapyr (140 g/ha), sulfometuron $(100 \mathrm{~g} / \mathrm{ha})$, and chlorsulfuron $(20 \mathrm{~g} / \mathrm{ha})$ were applied in the fall on rangeland sites near Ainsworth and Columbus, NE. Imidazolinone and sulfonylurea herbicide combinations did not improve leafy spurge control nor affect forage grass yields when compared with herbicides applied alone. Imazapyr and sulfometuron were the most efficacious, providing greater than $80 \%$ leafy spurge control 9 months after treatment (MAT). Imazethapyr provided $80 \%$ control of leafy spurge 9 MAT when applied to a coarse textured, low organic matter soil. In contrast, leafy spurge control was only $15 \%$ when imazethapyr was applied to a fine textured soil. Chlorsulfuron did not control leafy spurge, regardless of site characteristics. Imazapyr reduced perennial grass yields by more than $60 \%$.
\end{abstract}

\section{Nomenclature:}

Chlorsulfuron, 2-chloro- $N$-[[(4-methoxy-6-methyl-1,3,5-triazin-2-yl) amino]carbonyl]benzenesulfonamide; imazapyr,t-2-[4,5-dihydro-4-methyl4-(1-methylethyl)-5-oxo-1H-imidazol-2-yl]-3-pyridinecarboxylic acid; imazethapyr, 2-[4,5-dihydro-4-methyl-4-(1-methylethyl)-5-oxo-1H-imidazol-2-yl]-5-ethyl-3-pyridinecarboxlic acid; sulfometuron, 2-[[[[(4,6-dimethyl-2-pyrimidinyl)amino]carbonyl]amino] sulfonyl]benzoic acid; leafy spurge, Euphorbia esula L. \#² EPHES.

\footnotetext{
${ }^{1}$ Received for publication Nov. 29, 1993 and in revised form Apr. 8, 1994. Published as paper No. 10697, J. Ser., Nebraska Agric. Res. Div.

${ }^{2}$ Letters following this symbol are a WSSA-approved computer code from Composite List of Weeds, Revised 1989. Available from WSSA, 1508 West University Ave., Champaign, IL 61821-3133.
} 


\section{Additional index words:}

Noxious weeds, rangeland, chlorsulfuron, imazapyr, imazethapyr, sulfometuron, EPHES.

\section{Introduction}

Leafy spurge is an aggressive, perennial weed which infests rangeland, pasture, and non-cropland throughout the central and northern Great Plains of the United States. Leafy spurge is very competitive with forage grasses, eventually becoming the dominant species on infested sites. Leafy spurge causes economic losses by reducing forage production and livestock carrying capacity. Although the magnitude of the forage reduction varies with site characteristics, leafy spurge can decrease forage production by as much as $75 \%$ (5), posing a significant economic threat to livestock enterprises in the Great Plains.

Attempts to control leafy spurge with herbicides have met with limited success. The inability to maintain control is due largely to the regenerative capabilities of the deep, extensive root system. Production of new shoots from adventitious buds located on the crown and root system enables the plant to regrow vegetatively from a considerable depth $(9,10)$.

Picloram (4-amino-3,5,6-trichloro-2-pyridinecarboxylic acid) applied at $2.2 \mathrm{~kg}$ ae/ha can provide acceptable residual control, but is cost prohibitive for large infestations (6). Picloram plus 2,4-D [(2,4-dichlorophenoxy)acetic acid] at 0.28 and $1.1 \mathrm{~kg} / \mathrm{ha}$ is less costly, but annual applications are required to maintain acceptable control. Therefore, research to evaluate economical and environmentally sound alternatives to control leaf spurge is warranted.

Imidazolinone and sulfonylurea herbicides have not been extensively evaluated for leafy spurge control. These herbicides inhibit the plant enzyme acetolactate synthase, are readily translocated, and have soil residual activity $(2,7)$. Since imazethapyr and imazaquin $\{2$-[4,5-dihydro-4-methyl-4-(1-methylethyl)-5-oxo- $1 \mathrm{H}$-imidazol-2-yl]-3-quinolinecarboxylic acid $\}$ are labeled for the control of other Euphorbiaceae species, the imidazolinone herbicides may control leafy spurge. The objective of this research was to determine whether imidazolinone and sulfonylurea herbicides applied alone or in combination would control leafy spurge and not injure associated forage grasses.

\section{Materials and methods}

Experiments were conducted in 1988 and 1989 near Ainsworth, NE and in 1990 and 1991 near Columbus, NE on well-established, mature stands of leafy spurge. The Ainsworth site, a subirrigated meadow, was hayed annually in mid-July. Soil at the Ainsworth site was a Tryon loamy fine sand (mixed, mesic, Typic Psammaquents) with $1.7 \%$ or- 
ganic matter and $\mathrm{pH}$ 6.6. The Columbus site was a tallgrass prairie with a management history of moderate to heavy continuous grazing by cattle during spring and summer. Soil at the Columbus site was a Nora silty clay loam (mixed, mesic, Udic Haplustolls) with an organic matter content of $5.6 \%$ and $\mathrm{pH} 6.7$.

Grasses found in both sites included Kentucky bluegrass (Poa pratensis L.), smooth bromegrass (Bromus inennis L.), big bluestem (Andropogon gerardii Vitman var. gerardii Vitman), switchgrass (Panicum virgatum L.), and little bluestem [Schizachyrium scoparium (Michx.) Nash]. The sites were not grazed or hayed for the duration of the experiments. Vegetation that accumulated from the previous growing season was burned in early April each year when leafy spurge shoots were emerging to reduce interference with herbicide applications and vegetation sampling, and to facilitate the evaluation of treatments.

The initial experiment in 1988 included imazapyr (840 g/ha), imazethapyr (140 g/ha), sulfometuron (100 g/ha), chlorsulfuron (20 g/ha), imazapyr plus sulfometuron, and imazethapyr plus chlorsulfuron. Experiments conducted after 1988 included all possible combinations of imidazolinone plus sulfonylurea herbicides.

Herbicides were applied with a tractor-mounted, compressed-air sprayer delivering $187 \mathrm{~L} / \mathrm{ha}$ at $276 \mathrm{kPa}$. Herbicide treatments were applied in the fall of each year when most leafy spurge shoots were at a post-flower stage of development and plant height was between 50 and $70 \mathrm{~cm}$ (Table 1). Herbicide treatments included X-77 at $0.25 \%(\mathrm{v} / \mathrm{v})$. Individual plots were 5 by $8 \mathrm{~m}$ with a $1 \mathrm{~m}$ border between plots.

Table 1. Application, evaluation, and harvest dates for experimental sites near Ainsworth and Columbus, NE, 1988 to 1992.

\begin{tabular}{|c|c|c|c|c|}
\hline & \multicolumn{2}{|c|}{ Ainsworth } & \multicolumn{2}{|c|}{ Columbus } \\
\hline & 1988 & 1989 & 1990 & 1991 \\
\hline Application & Oct. 2, 1988 & Sept. 3, 1989 & Sept. 11,1990 & Sept. 30, 1991 \\
\hline \multicolumn{5}{|l|}{ Evaluation } \\
\hline Spring & May 31, 1989 & June 29, 1990 & June 6, 1991 & June 6, 1992 \\
\hline Fall & Oct. 2, 1989 & Sept. 25, 1990 & Aug. 14, 1991 & Aug. 9, 1992 \\
\hline Harvest & June 2, 1989 & June 29, 1990 & June 24, 1991 & June 25, 1992 \\
\hline
\end{tabular}

Leafy spurge control was visually estimated in all treatments about 9 and 11 MAT using a scale of 0 (no effect) to $100 \%$ (no stems present). Leafy spurge yields were determined in all experiments. Forage grass yields were measured in experiments conducted after 1988. Yield was determined about 10 MAT by clipping vegetation within two, $0.25-$ $\mathrm{m}^{2}$ quadrats per plot. Vegetation samples were separated into leafy spurge and grass, oven-dried at $60^{\circ} \mathrm{C}$ for 48 hours and weighed.

\footnotetext{
${ }^{3}$ X-77 Spreader, a mixture of alkylarylpolyoxyethylene glycols, free fatty acids, and isopropanol marketed by Valent U.S.A. Corp., 1333 N. California Blvd., Walnut Creek, CA 94596.
} 
Experiments were designed as randomized complete blocks with four replications. Due to treatment by year interactions, each experiment was analyzed separately. Univariate analysis and a plot of residuals were conducted on all response variables to determine if error was normally distributed (11). Nontreated plots were not included in the visual control analysis in an attempt to reduce heterogeneity of variance.

Error variance for the Columbus 1990 leafy spurge and forage grass yield data and the Columbus 1991 leafy spurge control and leafy spurge yield data were non-uniform and required transformation. Visual estimates of leafy spurge control were subjected to arcsine transformation and leafy spurge and forage grass yields were subjected to square root transformation before analysis to normalize residuals.

Data were subjected to analysis of variance, and treatment means were separated using Duncan's multiple range test at the 5\% level of probability. For transformed variables, analysis of variance and Duncan's Multiple Range test procedures were conducted on the transformed data set before back transforming the means.

\section{Results and discussion}

\section{Leafy spurge control and yield}

Leafy spurge control with imidazolinone and sulfonylurea herbicides was variable. At 9 MAT, leafy spurge control with imazapyr was consistently greater than $85 \%$ and, with the exception of 1988, was more efficacious than imazethapyr (Table 2). Leafy spurge control with imazethapyr varied by location. Imazethapyr provided at least $80 \%$ control at the Ainsworth site but only $15 \%$ at the Columbus site.

Table 2. Leafy spurge visual control ratings 9 and 11 months after treatment (MAT) of imidazolinone and sulfonylurea herbicides ${ }^{\mathrm{a}}$.

\begin{tabular}{|c|c|c|c|c|c|c|c|c|c|}
\hline \multirow[b]{4}{*}{ Herbicide } & \multirow[b]{4}{*}{ Rate } & \multicolumn{8}{|c|}{ Leafy spurge control } \\
\hline & & \multicolumn{4}{|c|}{$9 \mathrm{MAT}$} & \multicolumn{4}{|c|}{$11 \mathrm{MAT}$} \\
\hline & & \multicolumn{2}{|c|}{ Ainsworth } & \multicolumn{2}{|c|}{ Columbus } & \multicolumn{2}{|c|}{ Ainsworth } & \multicolumn{2}{|c|}{ Columbus } \\
\hline & & 1988 & 1989 & 1990 & $1991 b$ & 1988 & 1989 & 1990 & 1991 \\
\hline & $\mathrm{g} / \mathrm{ha}$ & ------- & -1---- & $\begin{array}{l}------ \\
\end{array}$ & ------ 9 & ------ & 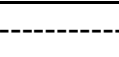 & $\begin{array}{l}------ \\
--1\end{array}$ & $\begin{array}{l}----- \\
--1\end{array}$ \\
\hline Imazapyr & 840 & $100 \mathrm{a}$ & $100 \mathrm{a}$ & $85 \mathrm{a}$ & $90 \mathrm{a}$ & $90 \mathrm{ab}$ & $65 \mathrm{a}$ & $80 \mathrm{a}$ & $45 \mathrm{~b}$ \\
\hline Imazethapyr & 140 & $85 \mathrm{a}$ & $80 \mathrm{~b}$ & $15 \mathrm{c}$ & $15 \mathrm{c}$ & $30 \mathrm{~d}$ & $25 \mathrm{bc}$ & $0 \mathrm{c}$ & $0 \mathrm{~d}$ \\
\hline Sulfometuron & 100 & $100 \mathrm{a}$ & $85 \mathrm{ab}$ & $85 \mathrm{a}$ & $95 \mathrm{a}$ & $40 \mathrm{~cd}$ & $15 \mathrm{bc}$ & $50 \mathrm{~b}$ & $30 \mathrm{bc}$ \\
\hline Chlorsulfuron & 20 & $20 \mathrm{~b}$ & $10 \mathrm{c}$ & $5 \mathrm{c}$ & $35 \mathrm{bc}$ & $45 \mathrm{~cd}$ & $10 \mathrm{bc}$ & $0 \mathrm{c}$ & $0 \mathrm{~d}$ \\
\hline Imazapyr + sulfometuron & $840+100$ & $100 \mathrm{a}$ & $100 \mathrm{a}$ & $100 \mathrm{a}$ & $100 \mathrm{a}$ & $95 \mathrm{a}$ & $40 \mathrm{abc}$ & $90 \mathrm{a}$ & $80 \mathrm{a}$ \\
\hline Imazapyr + chlorsulfuron & $840+20$ & - & $100 \mathrm{a}$ & $90 \mathrm{a}$ & $90 \mathrm{a}$ & - & $45 \mathrm{ab}$ & $75 \mathrm{a}$ & $40 \mathrm{~b}$ \\
\hline Imazethapyr + sulfometuron & $140+100$ & - & $80 \mathrm{~b}$ & $90 \mathrm{a}$ & $100 \mathrm{a}$ & - & $20 \mathrm{bc}$ & $50 \mathrm{~b}$ & $45 \mathrm{~b}$ \\
\hline Imazethapyr + chlorsulfuron & $140+20$ & $95 \mathrm{a}$ & $65 \mathrm{~b}$ & $30 \mathrm{~b}$ & $55 \mathrm{~b}$ & $65 \mathrm{bc}$ & $10 \mathrm{c}$ & $10 \mathrm{c}$ & $5 \mathrm{~cd}$ \\
\hline
\end{tabular}

Page 4 of 7 
Leafy spurge yield correlated well with percent control (Table 3). As percent control increased, leafy spurge yield decreased. There were no differences in leafy spurge yield between imazapyr and imazethapyr at Ainsworth (Table 4). In contrast, leafy spurge yield at Columbus was less after treatment with imazapyr than with imazethapyr. Leafy spurge yield on imazethapyr-treated plots was similar to that on nontreated plots.

Table 3. Spearman correlation coefficients ${ }^{\mathrm{a}}$ (r) between leafy spurge control $^{\mathrm{b}}$ and leafy spurge and forage grass yields.

\begin{tabular}{lccccc}
\hline & \multicolumn{3}{c}{ Ainsworth } & & \multicolumn{3}{c}{ Columbus } \\
\cline { 2 - 3 } \cline { 5 - 6 } Parameter & 1988 & 1989 & & 1990 & 1991 \\
\hline Leafy spurge yield & -0.97 & -0.96 & & -0.94 & -0.94 \\
Forage grass yield & - & -0.89 & & -0.36 & -0.10 \\
\hline
\end{tabular}

${ }^{a}$ Correlation was conducted on the treatment means for each experiment.

${ }^{\mathrm{b}}$ Leafy spurge control evaluation 9 months after treatment.

Differences in edaphic factors at Ainsworth and Columbus may explain variation in leafy spurge control with imazethapyr. Soil adsorption and imazethapyr efficacy have been shown to be affected by soil texture and organic matter (12). Higher clay and organic matter at Columbus may have reduced the amount of herbicide available for root uptake. Differences in soil properties did not appear to affect leafy spurge control with imazapyr. Although soil type and $\mathrm{pH}$ affect imazapyr and imazethapyr similarly, the higher imazapyr rate may have offset increased soil adsorption at Columbus (7).

Table 4. Leafy spurge and forage grass yield 10 months after treatment of imidazolinone and sulfonylurea herbicides ${ }^{\mathrm{a}}$.

\begin{tabular}{|c|c|c|c|c|c|c|c|c|}
\hline \multirow[b]{3}{*}{ Herbicide } & \multirow[b]{3}{*}{ Rate } & \multicolumn{4}{|c|}{ Leafy spurge yield } & \multicolumn{3}{|c|}{ Forage grass yield } \\
\hline & & \multicolumn{2}{|c|}{ Ainsworth } & \multicolumn{2}{|c|}{ Columbus } & \multirow{2}{*}{$\frac{\text { Ainsworth }}{1989}$} & \multicolumn{2}{|c|}{ Columbus } \\
\hline & & 1988 & 1989 & $1990^{\mathrm{b}}$ & $1991^{\mathrm{b}}$ & & $1990^{b}$ & 1991 \\
\hline & $\mathrm{g} / \mathrm{ha}$ & & & & $\mathrm{kg} / \mathrm{ha}$ & & & \\
\hline Imazapyr & 840 & $0 \mathrm{~b}$ & $55 \mathrm{bc}$ & $180 \mathrm{bc}$ & $160 \mathrm{def}$ & $295 \mathrm{c}$ & $410 \mathrm{~b}$ & $1120 \mathrm{~cd}$ \\
\hline Imazethapyr & 140 & $105 \mathrm{~b}$ & $510 a b c$ & $1250 \mathrm{a}$ & $1610 \mathrm{ab}$ & $1930 \mathrm{a}$ & $3565 \mathrm{a}$ & $2575 \mathrm{ab}$ \\
\hline Sulfometuron & 100 & $0 \mathrm{~b}$ & $455 \mathrm{abc}$ & $235 \mathrm{~b}$ & 80 ef & $850 \mathrm{bc}$ & $3875 \mathrm{a}$ & $2660 \mathrm{ab}$ \\
\hline Chlorsulfuron & 20 & $920 \mathrm{a}$ & $1100 \mathrm{a}$ & $1395 \mathrm{a}$ & 2940 a & $2130 \mathrm{a}$ & $3560 \mathrm{a}$ & $2150 a b c$ \\
\hline $\begin{array}{l}\text { Imazapyr + } \\
\text { sulfometuron }\end{array}$ & $840+100$ & $0 \mathrm{~b}$ & $0 \mathrm{c}$ & $10 \mathrm{c}$ & $5 \mathrm{f}$ & $55 \mathrm{c}$ & $655 \mathrm{~b}$ & $1290 \mathrm{bcd}$ \\
\hline $\begin{array}{l}\text { Imazapyr }+ \\
\text { chlorsulfuron }\end{array}$ & $840+20$ & - & $5 \mathrm{c}$ & $195 \mathrm{~b}$ & 415 cde & $425 \mathrm{c}$ & $595 \mathrm{~b}$ & $380 \mathrm{~d}$ \\
\hline $\begin{array}{l}\text { Imazethapyr + } \\
\text { sulfometuron }\end{array}$ & $140+100$ & - & $400 \mathrm{abc}$ & $95 \mathrm{bc}$ & $20 \mathrm{ef}$ & $660 \mathrm{bc}$ & $3285 \mathrm{a}$ & $3275 \mathrm{a}$ \\
\hline $\begin{array}{l}\text { Imazethapyr + } \\
\text { chlorsulfuron }\end{array}$ & $140+20$ & $45 \mathrm{~b}$ & $860 \mathrm{ab}$ & $1075 \mathrm{a}$ & $955 \mathrm{bcd}$ & $2615 \mathrm{a}$ & $2820 \mathrm{a}$ & $2285 a b c$ \\
\hline Nontreated & - & $1065 \mathrm{a}$ & $740 \mathrm{abc}$ & $1375 \mathrm{a}$ & $1075 \mathrm{abc}$ & $1620 \mathrm{ab}$ & $2870 \mathrm{a}$ & $2875 \mathrm{a}$ \\
\hline
\end{tabular}

Page 5 of 7 
Leafy spurge control 11 MAT was greater with imazapyr compared with imazethapyr (Table 2). Long-term leafy spurge control with imazapyr varied from 45 to $90 \%$ which is similar to that reported for picloram plus 2,4-D $(4,6)$. Imazethapyr failed to adequately control leafy spurge 11 MAT at either site.

Response of leafy spurge to imazethapyr in this study was similar to that observed by Masters et al. (8). Fall applied imazethapyr at $140 \mathrm{~g} /$ ha incompletely controlled leafy spurge at Ainsworth and Columbus in both studies. The one discrepancy between the studies was leafy spurge control 9 MAT at Ainsworth in 1989. This may have resulted from differences in leafy spurge distribution and composition of associated vegetation between areas used for each study. Despite this discrepancy, leafy spurge control was consistent between the two studies 11 MAT at Ainsworth and Columbus.

Leafy spurge responded differently to the sulfonylurea herbicides. Chlorsulfuron did not control leafy spurge. In contrast, sulfometuron provided greater than $80 \%$ control 9 MAT and reduced leafy spurge yield to the same level as imazapyr. Control with sulfometuron 11 MAT varied from 15 to $50 \%$ and was less than that provided by imazapyr each year except in 1991.

Generally, tank mixing imidazolinones and sulfonylurea herbicides did not improve leafy spurge control compared to the herbicides applied alone (Table 2). The one exception was in 1991 when the combination of imazapyr and sulfometuron which provided the best leafy spurge control at 11 MAT.

\section{Forage grass yield}

Imazapyr treatments caused the greatest reduction in forage grass yields (Table 4), resulting in an overall negative correlation with percent leafy purge control for all experiments (Table 3). In contrast, forage grass yield after treatment with imazethapyr were not different from the nontreated check. Fales et al. (3) observed dry matter yield reductions when imazethapyr as applied in the spring at $0.1 \mathrm{~kg} / \mathrm{ha}$ to stands of cool-season grasses that were less than 1 year old. The lack of yield reductions from imazethapyr in our research may be due to applications being made to well-established, grass lands.

Forage grass yield in areas treated with chlorsulfuron or sulfometuron were similar to the nontreated check at both sites (Table 4). During 1989, forage grass yield when sulfometuron was applied was less than that obtained from as treated with imazethapyr, chlorsulfuron, and imazethapyr plus chlorsulfuron. The low organic matter and clay content of the soil at Ainsworth may have resulted in greater sulfometuron availability and grass injury compared to the Columbus location.

Sulfometuron provided short-term leafy spurge control during each year of this study and did not reduce forage grass yield except in 1989. Although leafy spurge control with sulfometuron did not differ between locations, it appears that forage grass tolerance may be affected by edaphic factors. Beck et al. (1) observed $88 \%$ grass injury after treatment with sulfometuron. Additional research is needed to identify sulfometuron tolerant forage grass species and to determine the effects of soil properties on sulfometuron efficacy.

Forage grass injury caused by imazapyr would preclude the use of this herbicide for leafy spurge control except in noncrop or rangeland renovation programs. Imazethapyr

Page 6 of 7 
did not adversely affect forage grass yields, however, leafy spurge control declined when applied to a fine-textured soil. Higher imazethapyr rates may be required on similar sites to provide more reliable leafy spurge control. Several species of the leguminosae family are tolerant to imazethapyr (13), and its use for leafy spurge control would enhance species diversity in rangeland and pasture situations compared to currently available herbicides.

\section{Acknowledgments}

The authors acknowledge American Cyanamid Co. and the Nebraska Leafy Spurge Working Task Force for partial financial support of this research. The assistance of W. M. Thompson and K. Grams was greatly appreciated.

\section{Literature cited}

1. Beck, G. K., R. G. Lym, R. L Becker, M. A. Ferrell, D. W. Finnerty, R. J. Frank, M. A. Henson, and M. A. Peterson. 1993. Leafy spurge (Euphorbia esula) control and grass injury with sulfometuron. Weed Technol. 7:212-215.

2. Duke, S. O. 1990. Overview of herbicide mechanisms of action. Environ. Health Perspec. 87:263-271.

3. Fales, S. L., R. R. Hill, and R. J. Hoover. 1990. Chemical regulation of growth and forage quality of cool-season grasses with imazethapyr. Agron. J. 82:9-17.

4. Gylling, S. R. and V. E. Arnold. 1985. Efficacy and economics of leafy spurge (Euphorbia esula) control in pasture. Weed Sci. 33:381-385.

5. Lym, R. G. and D. R. Kirby. 1987. Cattle foraging behavior in leafy spurge (Euphorbia esula)-infested rangeland. Weed Technol. 1:314-318.

6. Lym, R. G. and C. G. Messersmith. 1990. Cost-effective long-term leafy spurge (Euphorbia esula) control with herbicides. Weed Technol. 4:635-641.

7. Mangels, G., 1991, Behavior of the imidazolinone herbicides in soil-A review of the literature. p. 191410 in Shiner, D. L. and S. L. O'Conner, eds. The Imidazolinone Herbicides. CRC Press, Inc., Boca Raton, FL.

8. Masters, R. A., R. N. Stougaard, and S. J. Nissen. 1994. Leafy spurge (Euphorbia esula) control with fall-applied imazapyr, imazaquin, and imazethapyr. Weed Technol. 8:58-63.

9. Morrow, L. A. 1979. Studies on the reproductive biology of leafy spurge (Euphorbia esula). Weed Sci. 27:106-109.

10. Raju, M. V. S. 1985. Morphology and anatomy of leafy spurge. p. 26-41 in Watson, A. K., ed. Leafy spurge. WeedSci. Soc. Am. Monogr. 3. Champaign, IL.

11. SAS Institute, Inc. 1988. p. 405-420 in SAS Procedures Guide. Release 6.03 ed. SAS Institute, Inc., Cary, NC.

12. Stougaard, R. N., P. J. Shea, and A. R. Martin. 1990. Effect of soil type and pH on adsorption, mobility and efficacy of imazaquin and imazethapyr. Weed Sci. 38:67-73.

13. Wilson, R. G, 1990. Effect of imazethapyr on six forage legumes. Proc. North Cent. Weed Sci. Soc. 45:64.

Page 7 of 7 